Jurnal e-GiGi (eG), Volume 2, Nomor 2, Juli-Desember 2014

\title{
GAMBARAN TINGKAT PENGETAHUAN SISWA TENTANG PENCABUTAN GIGI DI SMP NEGERI 2 LANGOWAN
}

\author{
${ }^{1}$ Gisela Harlindong \\ ${ }^{2}$ Ni Wayan Mariati \\ ${ }^{2}$ Bernat Hutagalung \\ ${ }^{1}$ Kandidat Skripsi Program Studi Pendidikan Dokter Gigi Fakultas Kedokteran \\ Universitas Sam Ratulangi Manado \\ ${ }^{2}$ Program Studi Pendidikan Dokter Gigi Fakultas Kedokteran \\ Universitas Sam Ratulangi Manado \\ Email: gisela.18.harlindong@gmail.com.
}

\begin{abstract}
Tooth extraction is one of the best solution to prevent the occurrence of abnormalities in the oral cavity. Tooth extraction often experience barriers, obstacles commonly occur in efforts dental care due to lack of knowledge of the people against the tooth extraction. The purpose of this study to describe the level of students' knowledge of tooth extraction in SMP Negeri 2 Langowan. This is a descriptive study with a total sample of 198 students taken by Slovin formula. The results showed that the students' knowledge of tooth extraction in SMP Negeri 2 Langowan in say less because of the students who answered correctly from the scoring just get a score of 822 , or by $46.1 \%$, while the students who answered incorrectly by $53.9 \%$. It takes the role of the government, schools and parents to improve the students' knowledge of oral health.
\end{abstract}

Keywords: knowledge, tooth extraction.

\begin{abstract}
Abstrak: Pencabutan gigi merupakan salah satu solusi terbaik untuk mencegah terjadinya kelainankelainan dalam rongga mulut. Pencabutan gigi kadang mengalami hambatan, umumnya hambatan yang terjadi pada upaya pelayanan kesehatan gigi akibat dari kurangnya pengetahuan masyarakat terhadap pencabutan gigi tersebut. Tujuan penelitian ini untuk mengetahui gambaran tingkat pengetahuan siswa tentang pencabutan gigi di SMP Negeri 2 Langowan. Penelitian ini bersifat deskriptif dengan jumlah sampel sebanyak 198 siswa yang diambil dengan rumus slovin. Hasil penelitian menunjukkan bahwa pengetahuan siswa tentang pencabutan gigi di SMP Negeri 2 Langowan di katakan kurang oleh karena siswa yang menjawab dengan benar dari hasil skoring hanya mendapatkan skor 822 atau sebesar 46,1 \% sedangkan siswa yang menjawab salah sebesar 53,9\%. Persentase pengetahuan siswa tentang indikasi pencabutan gigi sebesar $50 \%$, Persentase pengetahuan siswa tentang kontra indikasi pencabutan gigi sebesar 47,2\%. Persentase pengetahuan siswa tentang manfaat pencabutan gigi sebesar $38,9 \%$. Persentase pengetahuan siswa tentang efek samping gigi yang merupakan indikasi tetapi tidak dicabut sebesar 46,6\%.
\end{abstract}

Kata kunci: pengetahuan, pencabutan gigi.

Kesehatan merupakan hal yang sangat penting bagi setiap insan manusia, dalam kehidupan sehari-hari. Kesehatan pada dasarnya ditujukan untuk meningkatkan kesadaran, kemauan, dan kemampuan hidup sehat bagi setiap orang untuk mewujudkan derajat kesehatan yang optimal. Kesehatan gigi dan mulut merupakan bagian integral dari kesehatan umum, perlu mendapat perhatian dari pemerintah dan masyarakat. ${ }^{1}$

Gigi merupakan salah satu bagian tubuh yang berfungsi untuk mengunyah, berbicara dan mempertahankan bentuk muka, sehingga penting untuk menjaga kesehatan gigi sedini mungkin agar dapat bertahan lama dalam rongga mulut. 
Pencabutan gigi merupakan tindakan yang sangat kompleks yang melibatkan struktur tulang, jaringan lunak dalam rongga mulut serta keseluruhan bagian tubuh. Pencabutan gigi merupakan cara mudah untuk menghilangkan sakit gigi. ${ }^{2}$

Masalah terbesar yang di hadapi penduduk di Indonesia seperti juga di negara-negara berkembang lainnya di bidang kesehatan gigi dan mulut adalah penyakit jaringan keras gigi (caries dentin). Survei yang di lakukan di beberapa negara seperti Nepal, Jordania, Arab Saudi, Japan dan Iran menunjukkan bahwa indikasi pencabutan gigi yang utama ialah karies gigi dan penyakit periodontal. Di Indonesia, berdasarkan hasil Riset Kesehatan Dasar (RISKESDAS) tahun 2007 prevalensi penduduk yang mempunyai masalah gigi dan mulut adalah 23,4\% dan di provinsi Sulawesi Utara sendiri 29,8\% penduduk memiliki masalah gigi dan mulut. Usaha untuk mengatasinya belum memberikan hasil yang nyata bila diukur dengan indikator kesehatan gigi masyarakat. ${ }^{3,4}$

Gigi yang telah karies dalam pertimbangan dokter gigi bahwa sudah tidak dapat dilakukan perawatan, maka pencabutan gigi merupakan solusi terbaik untuk menghilangkan sakit/radang serta mencegah terjadinya infeksi maupun kelainan lainnya. Pencabutan gigi kadang mengalami hambatan, umumnya hambatan yang terjadi pada upaya pelayanan kesehatan gigi yaitu kurangnya pengetahuan masyarakat terhadap pencabutan gigi yang menyebabkan masyarakat takut ke dokter gigi. ${ }^{5,6}$

Remaja yang berusia 11-14 tahun berada pada masa terjadinya perubahan fisik, mental, dan psikososial yang cepat dan berdampak pada berbagai aspek kehidupannya. Pada masa ini mereka mulai memiliki kebebasan akan menyampaikan hak dan kewajibannya, mulai memilih sesuatu yang dianggap baik oleh dirinya, serta masa ingin mencari tahu sesuatu yang baru. Oleh karena itu dalam hal ini siswa sekolah menengah pertama (SMP) merupakan kelompok remaja yang usianya sangat relevan untuk diteliti mengenai tingkat pengetahuan mereka tentang pencabutan gigi.
Dalam survei awal peneliti di SMP Negeri 2 Langowan didapatkan bahwa masih ada hambatan yang terjadi dalam upaya pelayanan pencabutan gigi untuk kesehatan gigi dan mulut, antara lain kurangnya pengetahuan tentang pencabutan gigi dan faktor ekonomi keluarga.

Kecamatan Langowan merupakan daerah yang saat ini sementara berkembang pesat dalam pertumbuhan ekonomi maupun infrastruktur, oleh karena tahun 2014 ini akan di mekarkan menjadi daerah otonom baru yaitu Kota Langowan sehingga peneliti ingin meneliti pada siswa SMP di daerah sementara berkembang. Mengingat pentingnya pengetahuan tentang pencabutan gigi, dalam upaya peningkatan kesehatan gigi dan mulut serta belum pernah dilakukan penelitian tingkat pengetahuan di kecamatan Langowan tentang pencabutan gigi.

Berdasarkan latar belakang diatas, penulis ingin mengetahui dan mengkaji lebih lanjut sehingga penulis merasa perlu untuk melakukan penelitian deskriptif mengenai gambaran tingkat pengetahuan siswa tentang tindakan pencabutan gigi di SMP Negeri 2 Langowan.

\section{BAHAN DAN METODE}

Penelitian yang dilakukan yaitu penelitian deksriptif. Penelitian ini dilaksanakan di SMP Negeri 2 Langowan pada bulan Mei 2014. Populasi penelitian yaitu seluruh siswa yang terdaftar di SMP Negeri 2 Langowan, yang berjumlah 393 siswa. Sampel pada penelitian ini sebanyak 198 orang berdasarkan perhitungan Slovin dengan teknik stratified random sampling. Data diolah berdasarkan distribusi frekuensi dan disajikan dalam bentuk tabel kemudian dianalisis secara deskriptif berdasarkan hasil persentase.

\section{HASIL PENELITIAN}

Pada penelitian ini, pengetahuan tentang pencabutan gigi menggunakan bantuan melalui kuesioner dengan 9 pertanyaan, yang dapat dilihat pada tabel berikut. 
Harlindong, Mariati, Hutagalung; Gambaran Tingkat Pengetahuan Siswa...

Tabel 1. Distribusi pengetahuan siswa tentang gigi susu harus dicabut apabila gigi tetap penggantinya akan tumbuh.

\begin{tabular}{cccccc}
\hline \multirow{2}{*}{ Kelas } & \multirow{2}{*}{ Sampel } & \multicolumn{2}{c}{ Benar } & \multicolumn{2}{c}{ Salah } \\
\cline { 3 - 6 } & & $\mathbf{n}$ & $\mathbf{\%}$ & $\mathbf{n}$ & $\mathbf{\%}$ \\
\hline VII & 57 & 30 & 52,6 & 27 & 47,4 \\
VIII & 67 & 34 & 50,7 & 33 & 49,3 \\
IX & 74 & 38 & 51,4 & 36 & 48,6 \\
\hline Jumlah & 198 & 102 & 51,6 & 96 & 48,4
\end{tabular}

Tabel 2. Distribusi pengetahuan siswa tentang gigi tetap harus dicabut apabila gigi tersebut sudah tidak dapat dipertahankan untuk dilakukan perawatan.

\begin{tabular}{cccccc}
\hline \multirow{2}{*}{ Kelas } & \multirow{2}{*}{ Sampel } & \multicolumn{2}{c}{ Benar } & \multicolumn{2}{c}{ Salah } \\
\cline { 3 - 6 } & & $\mathbf{n}$ & $\mathbf{\%}$ & $\mathbf{n}$ & $\mathbf{\%}$ \\
\hline VII & 57 & 22 & 38,6 & 35 & 61,4 \\
VIII & 67 & 30 & 44,8 & 37 & 55,2 \\
IX & 74 & 34 & 45,9 & 40 & 54,1 \\
\hline Jumlah & 198 & 86 & 43,1 & 112 & 56,9
\end{tabular}

Tabel 3. Distribusi pengetahuan siswa tentang gigi susu yang sudah harus dicabut biasanya ditandai dengan kegoyahan gigi.

\begin{tabular}{cccccc}
\hline \multirow{2}{*}{ Kelas } & \multirow{2}{*}{ Sampel } & \multicolumn{2}{c}{ Benar } & \multicolumn{2}{c}{ Salah } \\
\cline { 3 - 6 } & & $\mathbf{n}$ & $\mathbf{\%}$ & $\mathbf{n}$ & $\mathbf{\%}$ \\
\hline VII & 57 & 30 & 52,6 & 27 & 47,4 \\
VIII & 67 & 36 & 53,7 & 31 & 46,3 \\
IX & 74 & 43 & 58,1 & 31 & 41,9 \\
\hline Jumlah & 198 & 109 & 54,8 & 89 & 45,2
\end{tabular}

Tabel 4. Distribusi pengetahuan siswa tentang pencabutan gigi belum bisa dilakukan jika gigi masih dalam keadaan sakit.

\begin{tabular}{cccccc}
\hline \multirow{2}{*}{ Kelas } & \multirow{2}{*}{ Sampel } & \multicolumn{2}{c}{ Benar } & \multicolumn{2}{c}{ Salah } \\
\cline { 3 - 6 } & & $\mathbf{n}$ & $\mathbf{\%}$ & $\mathbf{n}$ & $\mathbf{\%}$ \\
\hline VII & 57 & 26 & 45,6 & 31 & 54,4 \\
VIII & 67 & 29 & 43,3 & 38 & 56,7 \\
IX & 74 & 39 & 52,7 & 35 & 47,3 \\
\hline Jumlah & 198 & 94 & 47,2 & 104 & 52,8
\end{tabular}

Tabel 5. Distribusi pengetahuan siswa tentang pencabutan gigi dapat mencegah terjadinya penyebaran infeksi berlanjut.

\begin{tabular}{cccccc}
\hline \multirow{2}{*}{ Kelas } & \multirow{2}{*}{ Sampel } & \multicolumn{2}{c}{ Benar } & \multicolumn{2}{c}{ Salah } \\
\cline { 3 - 6 } & & $\mathbf{n}$ & $\mathbf{\%}$ & $\mathbf{n}$ & $\mathbf{\%}$ \\
\hline VII & 57 & 15 & 26,3 & 42 & 73,7 \\
VIII & 67 & 29 & 43,3 & 38 & 56,7 \\
IX & 74 & 28 & 37,8 & 46 & 62,2 \\
\hline Jumlah & 198 & 72 & 35,8 & 126 & 64,2
\end{tabular}

Tabel 6. Distribusi pengetahuan siswa tentang pencabutan pada gigi susu yang tepat waktu dapat membuat pertumbuhan gigi penggantinya teratur dan mencegah terjadinya kelainan pertumbuhan gigi.

\begin{tabular}{cccccc}
\hline \multirow{2}{*}{ Kelas } & \multirow{2}{*}{ Sampel } & \multicolumn{2}{c}{ Benar } & \multicolumn{2}{c}{ Salah } \\
\cline { 3 - 6 } & & $\mathbf{n}$ & $\mathbf{\%}$ & $\mathbf{n}$ & $\mathbf{\%}$ \\
\hline VII & 57 & 23 & 40,4 & 34 & 59,6 \\
VIII & 67 & 27 & 40,3 & 40 & 59,7 \\
IX & 74 & 32 & 43,2 & 42 & 56,8 \\
\hline Jumlah & 198 & 82 & 41,4 & 116 & 58,6
\end{tabular}

Tabel 7. Distribusi pengetahuan siswa tentang keterlambatan pencabutan gigi susu mengakibatkan gigi tetap akan terhambat pertumbuhannya, sehingga menyebabkan susunan gigi geligi tetap tidak akan beraturan.

\begin{tabular}{cccccc}
\hline Kelas & Sampel & \multicolumn{2}{c}{ Benar } & \multicolumn{2}{c}{ Salah } \\
\cline { 3 - 6 } & & n & \% & n & \% \\
\hline VII & 57 & 24 & 42,1 & 33 & 57,9 \\
VIII & 67 & 31 & 46,3 & 36 & 53,7 \\
IX & 74 & 35 & 47,3 & 39 & 52,7 \\
\hline Jumlah & 198 & 90 & 45,5 & 108 & 54,5
\end{tabular}

Tabel 8. Distribusi pengetahuan siswa tentang gigi yang telah rusak tetapi tidak dicabut akan menyebabkan bau mulut.

\begin{tabular}{cccccc}
\hline Kelas & Sampel & \multicolumn{2}{c}{ Benar } & \multicolumn{2}{c}{ Salah } \\
\cline { 3 - 6 } & & n & \% & n & \% \\
\hline VII & 57 & 17 & 29,8 & 40 & 70,8 \\
VIII & 67 & 25 & 37,3 & 42 & 62,7 \\
IX & 74 & 34 & 46 & 40 & 54 \\
\hline Jumlah & 198 & 76 & 38,4 & 122 & 61,6
\end{tabular}

Tabel 9. Distribusi pengetahuan siswa tentang gigi yang telah rusak tetapi tidak dicabut akan terasa sakit atau meradang dalam jangka waktu yang lama.

\begin{tabular}{cccccc}
\hline Kelas & Sampel & \multicolumn{2}{c}{ Benar } & \multicolumn{2}{c}{ Salah } \\
\cline { 3 - 6 } & & n & \% & n & \% \\
\hline VII & 57 & 31 & 54,4 & 26 & 45,6 \\
VIII & 67 & 35 & 52,2 & 32 & 47,8 \\
IX & 74 & 45 & 60,8 & 29 & 39,2 \\
\hline Jumlah & 198 & 111 & 56,1 & 87 & 43,9
\end{tabular}

\section{BAHASAN}

Distribusi pengetahuan siswa tentang gigi susu harus dicabut apabila gigi tetap penggantinya akan tumbuh dalam tabel 1 menunjukkan bahwa pada siswa kelas VII dengan sampel 57 siswa terdapat 52,6\% 
siswa yang mengatakan benar dan 47,4\% siswa yang mengatakan salah. Pada siswa kelas VIII dengan sampel 67 siswa terdapat $50,7 \%$ siswa yang mengatakan benar dan 49,3\% siswa yang mengatakan salah. Pada siswa kelas IX dengan 74 sampel siswa terdapat $51,4 \%$ siswa yang mengatakan benar dan 48,6\% siswa yang mengatakan salah. Secara keseluruhan pengetahuan siswa tentang gigi susu harus dicabut apabila gigi tetap penggantinya akan tumbuh pada 198 sampel, didapatkan bahwa $51,6 \%$ siswa mengatakan benar dan 48,4\% siswa mengatakan salah. Hal ini menunjukkan bahwa tingkat pengetahuan siswa tentang gigi susu harus dicabut apabila gigi tetap penggantinya akan tumbuh dapat dikatakan baik.

Distribusi pengetahuan siswa tentang gigi susu yang sudah harus dicabut biasanya ditandai dengan kegoyahan gigi dalam tabel 3 menunjukkan bahwa pada siswa kelas VII dengan sampel 57 siswa terdapat 52,6\% siswa yang mengatakan benar dan 47,4\% siswa yang mengatakan salah. Pada siswa kelas VIII dengan sampel 67 siswa terdapat $53,7 \%$ siswa yang mengatakan benar dan $46,3 \%$ siswa yang mengatakan salah. Pada siswa kelas IX dengan 74 sampel siswa terdapat $58,1 \%$ siswa yang mengatakan benar dan $41,9 \%$ siswa yang mengatakan salah. Secara keseluruhan pengetahuan siswa tentang gigi susu yang sudah harus dicabut biasanya ditandai dengan kegoyahan gigi pada 198 sampel didapatkan bahwa $54,8 \%$ siswa mengatakan benar dan 45,2\% siswa mengatakan salah. Untuk pengetahuan siswa tentang gigi susu yang sudah harus dicabut biasanya ditandai dengan kegoyahan gigi dapat dikatakan baik.

Hal ini karena sudah semakin tahunya masyarakat bahwa gigi susu yang tidak dicabut apabila gigi tetap penggantinya akan tumbuh dapat menyebabkan gigi berjejal (tidak teratur), gigi berjarak serta berbagai kelainan lainnya. Hasil penelitian ini sesuai dengan penelitian yang dilakukan Dewanti di Depok pada anak usia sekolah tentang tingkat pengetahuan siswa mengenai hubungan tingkat pengetahuan kesehatan gigi dengan prilaku perawatan gigi pada anak usia sekolah di Depok pada tahun 2012 yang menunjukkan 58,9\% responden mengetahui tentang cara perawatan gigi yang benar yaitu gigi susu yang sudah harus dicabut biasanya ditandai dengan kegoyahan gigi. ${ }^{7}$

Distribusi pengetahuan siswa tentang gigi tetap harus dicabut, apabila gigi tersebut sudah tidak dapat dipertahankan untuk dilakukan perawatan dalam tabel 2 menunjukkan bahwa pada siswa kelas VII dengan sampel 57 siswa, terdapat 38,6\% siswa yang mengatakan benar dan 61,4\% siswa yang mengatakan salah. Pada siswa kelas VIII dengan sampel 67 siswa terdapat 44,8\% siswa yang mengatakan benar, dan $55,2 \%$ siswa yang mengatakan salah. Pada siswa kelas IX dengan 74 sampel siswa terdapat $45,9 \%$ siswa yang mengatakan benar, dan $54,1 \%$ siswa yang mengatakan salah. Secara keseluruhan pengetahuan siswa tentang gigi tetap harus dicabut apabila gigi tersebut sudah tidak dapat dipertahankan untuk dilakukan perawatan, pada 198 sampel didapatkan bahwa 43,1\% siswa mengatakan benar dan 56,9\% siswa mengatakan salah. Untuk pengetahuan siswa tentang gigi tetap harus dicabut apabila gigi tersebut sudah tidak dapat dipertahankan untuk dilakukan perawatan dapat dikatakan kurang.

Distribusi pengetahuan siswa tentang pencabutan gigi dapat mencegah terjadinya penyebaran infeksi berlanjut dalam tabel 5 menunjukkan bahwa pada siswa kelas VII dengan sampel 57 siswa terdapat 26,3\% siswa yang mengatakan benar dan 73,7\% siswa yang mengatakan salah. Pada siswa kelas VIII dengan sampel 67 siswa terdapat 43,3\% siswa yang mengatakan benar dan $56,7 \%$ siswa yang mengatakan salah. Pada siswa kelas IX dengan 74 sampel siswa terdapat $37,8 \%$ siswa yang mengatakan benar dan 62,2\% siswa yang mengatakan salah. Secara keseluruhan pengetahuan siswa tentang pencabutan gigi dapat mencegah terjadinya penyebaran infeksi berlanjut pada 198 sampel didapatkan bahwa 35,8\% siswa mengatakan benar dan $64,2 \%$ siswa mengatakan salah. Untuk pengetahuan siswa tentang pencabutan gigi dapat mencegah terjadinya penyebaran infeksi berlanjut dapat dikatakan kurang. 
Harlindong, Mariati, Hutagalung; Gambaran Tingkat Pengetahuan Siswa...

Hal ini karena masih kurangnya dilakukan penyuluhan tentang kesehatan gigi dan mulut sehingga para siswa ini tidak mengetahui efek samping dari gigi yang telah rusak dan tidak dapat dilakukan perawatan namun tidak dicabut. Hasil penelitian ini sejalan dengan penelitian yang telah dilakukan Cahyadi di Jogjakarta tahun 2009 yang meneliti tentang tingkat pengetahuan dan tindakan masyarakat tentang pencabutan gigi di Jogjakarta dengan responden yang berumur 17-45 tahun menunjukkan bahwa hanya 46,5\% responden mengetahui pencabutan gigi dapat mencegah penyebaran infeksi. ${ }^{8}$ Berbeda yang dilaporkan oleh Bayu R.E Warouw yang meneliti tentang gambaran tingkat pengetahuan masyarakat tentang pencabutan gigi di Kabupaten Minahasa Tenggara tahun 2014 dengan responden berumur 17-45 tahun didapatkan bahwa $77 \%$ responden mengetahui pencabutan gigi yang rusak sebaiknya dicabut daripada membiarkan. $^{9}$ Hasil ini dapat berbeda mungkin dikarenakan perbedaan umur responden sehingga semakin dewasanya seseorang maka informasi tentang kesehatan gigi dan mulut dapat semakin banyak.

Distribusi pengetahuan siswa tentang pencabutan gigi belum bisa dilakukan jika gigi masih dalam keadaan sakit dalam tabel 4 menunjukkan bahwa pada siswa kelas VII dengan sampel 57 siswa terdapat 45,6\% siswa yang mengatakan benar, dan 54,4\% siswa yang mengatakan salah. Pada siswa kelas VIII dengan sampel 67 siswa terdapat 43,3\% siswa yang mengatakan benar dan $56,7 \%$ siswa yang mengatakan salah. Pada siswa kelas IX dengan 74 sampel siswa terdapat 52,7\% siswa yang mengatakan benar dan 35 47,3\% siswa yang mengatakan salah. Secara keseluruhan pengetahuan siswa tentang pencabutan gigi belum bisa dilakukan jika gigi masih dalam keadaan sakit pada 198 sampel didapatkan bahwa 47,2\% siswa mengatakan benar dan 104 $52,8 \%$ siswa mengatakan salah. Untuk Pengetahuan siswa tentang pencabutan gigi belum bisa dilakukan jika gigi masih dalam keadaan sakit dapat dikatakan kurang.
Distribusi pengetahuan siswa tentang pencabutan pada gigi susu yang tepat waktu, dapat membuat pertumbuhan gigi penggantinya teratur dan mencegah terjadinya kelainan pertumbuhan gigi dalam tabel 6 menunjukkan bahwa pada siswa kelas VII dengan sampel 57 siswa terdapat 40,4\% siswa yang mengatakan benar dan $59,6 \%$ siswa yang mengatakan salah. Pada siswa kelas VIII dengan sampel 67 siswa terdapat $40,3 \%$ siswa yang mengatakan benar dan 59,6\% siswa yang mengatakan salah. Pada siswa kelas IX dengan 74 sampel siswa terdapat $43,2 \%$ siswa yang mengatakan benar dan 56,8\% siswa yang mengatakan salah. Secara keseluruhan pengetahuan siswa tentang pencabutan pada gigi susu yang tepat waktu dapat membuat pertumbuhan gigi penggantinya teratur dan mencegah terjadinya kelainan pertumbuhan gigi pada 198 sampel didapatkan bahwa 41,4\% siswa mengatakan benar dan 58,6\% siswa mengatakan salah. Untuk pengetahuan siswa tentang pencabutan pada gigi susu yang tepat waktu dapat membuat pertumbuhan gigi penggantinya teratur dan mencegah terjadinya kelainan pertumbuhan gigi dapat dikatakan kurang.

Distribusi pengetahuan siswa tentang gigi yang telah rusak tetapi tidak dicabut akan menyebabkan bau mulut dalam tabel 8 menunjukkan bahwa pada siswa kelas VII dengan sampel 57 siswa terdapat 29,8\% siswa yang mengatakan benar dan 70,8\% siswa yang mengatakan salah. Pada siswa kelas VIII dengan sampel 67 siswa terdapat $37,3 \%$ siswa yang mengatakan benar dan $62,7 \%$ siswa yang mengatakan salah. Pada siswa kelas IX dengan 74 sampel siswa terdapat $46 \%$ siswa yang mengatakan benar dan 54\% siswa yang mengatakan salah. Secara keseluruhan pengetahuan siswa tentang gigi yang telah rusak tetapi tidak dicabut akan menyebabkan bau mulut pada 198 sampel didapatkan bahwa 38,4\% siswa mengatakan benar dan $61,6 \%$ siswa mengatakan salah. Untuk pengetahuan siswa tentang gigi yang telah rusak tetapi tidak dicabut akan menyebabkan bau mulut dapat dikatakan kurang. 
Distribusi pengetahuan siswa tentang keterlambatan pencabutan gigi susu mengakibatkan gigi tetap akan terhambat pertumbuhannya sehingga menyebabkan susunan gigi geligi tetap tidak akan beraturan dalam tabel 7 menunjukkan bahwa pada siswa kelas VII dengan sampel 57 siswa terdapat 42,1\% siswa yang mengatakan benar dan 57,9\% siswa yang mengatakan salah. Pada siswa kelas VIII dengan sampel 67 siswa terdapat 46,3\% siswa yang mengatakan benar dan 53,7\% siswa yang mengatakan salah. Pada siswa kelas IX dengan 74 sampel siswa terdapat 47,3\% siswa yang mengatakan benar dan $52,7 \%$ siswa yang mengatakan salah. Secara keseluruhan pengetahuan siswa tentang keterlambatan pencabutan gigi susu mengakibatkan gigi tetap akan terhambat pertumbuhannya sehingga menyebabkan susunan gigi geligi tetap tidak akan beraturan pada 198 sampel didapatkan bahwa 45,5\% siswa mengatakan benar dan 54,5\% siswa mengatakan salah. Untuk pengetahuan siswa tentang keterlambatan pencabutan gigi susu mengakibatkan gigi tetap akan terhambat pertumbuhannya sehingga menyebabkan susunan gigi geligi tetap tidak akan beraturan dapat dikatakan kurang.

Sedikitnya informasi yang dimiliki para siswa tentang kesehatan gigi dan mulut sangat berpengaruh dalam menjaga kesehatan gigi dan mulut mereka. Usaha yang dapat dilakukan dalam menangani masalah kesehatan gigi adalah Usaha Kesehatan Gigi Sekolah (UKGS). UKGS ini merupakan bagian integral dari usaha kesehatan sekolah yang melakukan pelayanan kesehatan gigi dan mulut terencana. Beberapa kendala yang di alami UKGS sehingga tidak berjalan maksimal karena keterbatasan obat-obatan dan tenaga kesehatan/dokter gigi. Peran orang tua juga sangat dibutuhkan karena memiliki peran besar dalam memberikan informasi tentang kesehatan gigi dan mulut karena anak lebih banyak menghabiskan waktu di rumah. ${ }^{7}$

Hal ini didukung oleh N.Hutabarat yang melakukan penelitian tentang peran petugas kesehatan, guru dan orang tua dalam melaksanakan UKGS dengan tindakan pemeliharaan kesehatan gigi dan mulut murid sekolah di Kota Medan Tahun 2009. Hasil penelitian tersebut menunjukkan pengetahuan anak tentang pemeliharaan kesehatan gigi dan mulut masih rendah. Faktor yang mempengaruhi rendahnya pengetahuan antara lain karena sumber informasi pengetahuan yang kurang mendalam tentang kesehatan gigi. ${ }^{10}$

Distribusi pengetahuan siswa tentang gigi yang telah rusak tetapi tidak dicabut akan terasa sakit atau meradang dalam jangka waktu yang lama dalam tabel 9 menunjukkan bahwa pada siswa kelas VII dengan sampel 57 siswa terdapat 54,4\% siswa yang mengatakan benar dan 26 45,6\% siswa yang mengatakan salah. Pada siswa kelas VIII dengan sampel 67 siswa terdapat $52,2 \%$ siswa yang mengatakan benar dan $47,8 \%$ siswa yang mengatakan salah. Pada siswa kelas IX dengan 74 sampel siswa terdapat 60,8 siswa yang mengatakan benar dan 39,2\% siswa yang mengatakan salah. Secara keseluruhan pengetahuan siswa tentang gigi yang telah rusak tetapi tidak dicabut akan terasa sakit atau meradang dalam jangka waktu yang lama pada 198 sampel didapatkan bahwa 56,1\% siswa mengatakan benar dan 43,9\% siswa mengatakan salah. Untuk pengetahuan siswa tentang gigi yang telah rusak tetapi tidak dicabut akan terasa sakit atau meradang dalam jangka waktu yang lama dapat dikatakan baik.

Hal ini telah dipahami bahwa membiarkan gigi yang telah rusak didalam mulut, akan menyebabkan lebih parah lagi rasa sakit yang mereka derita serta berbagai efek samping yang dirasakan. Hasil penelitian ini sejalan dengan Bayu Warouw yang dalam penelitiannya pada masyarakat di Kabupaten Minahasa Tenggara tahun 2014 didapatkan bahwa $85 \%$ responden mengetahui pencabutan gigi membantu menjaga kesehatan mulut. ${ }^{9}$

Pengetahuan adalah hasil dari tahu dan ini terjadi setelah seseorang melakukan penginderaan pada objek tertentu. Pada masa remaja memiliki tanda awal dengan munculnya reflektifitas dan kecenderungan untuk ingin tahu tentang keadaan sekitar 
Harlindong, Mariati, Hutagalung; Gambaran Tingkat Pengetahuan Siswa...

yang sedang terjadi serta keadaan yang mempengaruhi keadaan fisiknya. Berbagai faktor seperti pendidikan formal, pendidikan informal serta sosial ekonomi akan mempengaruhi tingkat pengetahuan dari seseorang. ${ }^{11,12}$

Berdasarkan hasil penelitian yang didapatkan, pengetahuan siswa tentang pencabutan gigi di SMP Negeri 2 Langowan dapat di katakan kurang oleh karena siswa yang menjawab dengan benar dari hasil skoring hanya mendapatkan skor 822 atau sebesar 46,1\% sedangkan siswa yang menjawab salah sebesar 53,9\%. Berbagai faktor yang mempengaruhi kurangnya pengetahuan siswa diantaranya yaitu kurangnya informasi yang didapatkan siswa dari sekolah, keadaan lingkungan yang tidak mendukung serta faktor ekonomi keluarga yang sebagian besar berada di tingkat ekonomi menengah kebawah.

Hasil penelitian ini didukung oleh penelitian yang dilakukan oleh U.Kawuryan pada anak sekolah di Surakarta tahun 2008 menunjukkan bahwa tingkat pengetahuan anak usia sekolah di Kecamatan Laweyan Surakarta dengan responden berumur 11-17 tahun sebagian besar dalam kategori sedang. ${ }^{13}$ Hal yang sama dikemukakan oleh Dewanti di Depok yang meneliti pada anak usia sekolah mengenai hubungan tingkat pengetahuan kesehatan gigi dengan prilaku perawatan gigi pada anak usia sekolah pada tahun 2012 yang menunjukkan pengetahuan tentang kesehatan gigi dan mulut masih rendah. ${ }^{7}$

\section{SIMPULAN}

Dari penelitian ini dapat disimpulkan bahwa:

1. Persentase pengetahuan siswa SMP Negeri 2 Langowan tentang indikasi pencabutan gigi sebesar $50 \%$.

2. Persentase pengetahuan siswa SMP Negeri 2 Langowan tentang kontra indikasi pencabutan gigi sebesar 47,2\%.

3. Persentase pengetahuan siswa SMP Negeri 2 Langowan tentang manfaat pencabutan gigi sebesar 38,9\%.
4. Persentase pengetahuan siswa SMP Negeri 2 Langowan tentang efek samping gigi yang merupakan indikasi tetapi tidak di cabut sebesar $46,6 \%$.

\section{SARAN}

Bagi pihak sekolah dan puskesmas agar mengaktifkan kembali UKS/UKGS disekolah serta program DHE dan preventif dentistry untuk meningkatkan pengetahuan siswa tentang kesehatan gigi dan mulut. Perlu adanya peran orang tua di rumah dalam memberikan pengetahuan dasar tentang kesehatan gigi dan mulut.

\section{DAFTAR PUSTAKA}

1. Departemen Kesehatan RI. Rencana Strategis Departemen Kesehatan [Online]. 2005 Available from URL: http://www.depkes.go.id/admin/rencana/620 88136

2. Riyanto A. Penatalaksanaan Pelayanan Kesehatan Gigi Masyarakat. Yogyakarta: Penerbit Nuha Medika; 2011.hal.1-3

3. Panelewen AW. Gambaran Pencabutan Gigi Permanen di Puskesmas Bitung Barat Kecamatan Maesa Kota Bitung Tahun 2012. Program Studi Kedokteran Gigi Universitas Samratulangi; 2012. (Skripsi)

4. Badan Penelitian dan Pengembangan Kesehatan Departemen Kesehatan Republik Indonesia. Riset Kesehatan Dasar (RISKESDAS) tahun 2007. Jakarta DEPKES 2008. hal.131.

5. Prianggoro H. Cabut Gigi Harus Hati-Hati [online]. 2010 [cited 2014 mar 12].

Available from URL: http://www.kesehatan. kompas.com/read/2010/02/10/1712188/cabu t.gigi.

6. Panawar A. Seputar Kesehatan Gigi dan Mulut. Yogyakarta: Percetakan Andi Offset; 2013.hal.10-2

7. Dewanti. Hubungan Tingkat Pengetahuan Kesehatan Gigi Dengan Prilaku Perawatan Gigi Pada Anak Usia Sekolah di Depok. Universitas Indonesia; 2012. (Skripsi)

8. Cahyadi. Tingkat Pengetahuan dan Tindakan Masyarakat Tentang Pencabutan Gigi di Kelurahan Lilibang. UGM Jogjakarta; 2009. (Skripsi)

9. Warouw Bayu. Gambaran Tingkat Pengetahuan dan Sikap Masyarakat Tentang Pencabutan Gigi di Desa Molompar Utara 
Jurnal e-GiGi (eG), Volume 2, Nomor 2, Juli-Desember 2014

Kabupaten Minahasa Tenggara. Program Studi Pendidikan Dokter Gigi Universitas Sam Ratulangi; 2014. (Skripsi)

10. Hutabarat N. Peran Petugas Kesehatan, Guru dan Orang tua dalam melaksanakan UKGS Dengan Tindakan Pemeliharaan Kesehatan Gigi dan Mulut Murid Sekolah Dasar di Kota Medan; Universitas Sumatera Utara; 2009. (Skripsi)
11. Wawan A, Dewi M. Teori dan Pengukuran Pengetahuan, Sikap dan Perilaku Manusia. Yogyakarta: Nuha Medika; 2010. hal.12

12. Ali M. Dkk. Psikologi Remaja. Perkembangan Peserta Didik. Jakarta. PT Bumi Aksara; 2009.hal.5-6

13. Kawuryan U. Hubungan Pengetahuan Tentang Kesehatan Gigi dan Mulut Dengan Kejadian Karies Pada Anak Usia Sekolah di Kecamatan Laweyan Surakarta; Universitas Muhammadiyah Surakarta; 2008. (Skripsi) 